\title{
Prostate Cancer pNX TNM Finding v6 and v7
}

National Cancer Institute

\section{Source}

National Cancer Institute. Prostate Cancer pNX TNM Finding v6 and v7. NCI Thesaurus. Code C52682.

Prostate cancer in which the regional lymph nodes were not sampled. (from AJCC 6th and 7th Eds.) 